\title{
MORE AMERICAN SPIDERS OF THE GENUS CHRYSSO (ARANEAE, THERIDIIDAE)*
}

\author{
By Herbert W. Levi \\ Museum of Comparative Zoology, Harvard University
}

In a previous paper (Levi, I955) I revised the genus Chrysso, which I thought at the time to be a compact group of closely related species quite distinct from Theridion, and all coming from America. However, soon after publishing a description of the genus Arctachaea for only two species (Levi, I957), I discovered species intermediate between the new genus and Chrysso.

Though species bridging genera have been found in various groups of theridiids, it was a surprise to see the description of Argyria venusta Yaginuma, 1957 (Figs. 3-5) from Japan, a species close to Chrysso and having similar habits, but less specialized in genitalic structure. Soon several other species were examined that are best placed in Chrysso unless we want numerous monotypic genera. One of these species is Argyrodes nigra O. P.-Cambridge (Figs. I, 2) from Ceylon (with genitalia superficially resembling those of Theridion punctosparsum Emerton) though it has the palpus still less specialized than does Chrysso venusta (Yaginuma). Allied to Chrysso nigra (O. P.-Cambridge) is the American Chrysso nigrosternum Keyserling (Fig. 13). Several of the species now placed in Chrysso have the cymbium modified [e.g. Chrysso perplexa (Keyserling), Fig. I8], and bridge the gap to the two species previously placed in Arctachaea. Further, a male of Chrysso cambridgei (Petrunkevitch) (Figs. 43-47) bridges the gap between the latter groups and the species tentatively placed in Meotipa. Meotipa is a genus of doubtful validity; the male of the type species remains unknown. The three species placed in Meotipa differed from Chrysso mainly by their longer legs and by a somewhat different shape of abdomen.

There is still some doubt that the groups considered in this paper are monophyletic. Certainly all are related to Theridion, from which they can be separated by the modified shape of the abdomen and by the more specialized palpus. The specialization of the palpus, however, may go in different directions. Most species resemble the $T$. frondeum group. A distally truncate cymbium, otherwise rare in theridiids, is common in Chrysso and probably indicates relationship. Another unusual character, grooves on the sides of the abdomen, is found in some of the species here considered to belong to Chrysso and

*Manuscript received by the editor April 18, 1962. 
may be further evidence of common origin. In addition, several species have teeth on the posterior margin of the chelicerae.

I would like to thank Dr. W. J. Gertsch for the loan of collections from the American Museum of Natural History (AMNH) ; Dr. A. M. Chickering for large collections from Panama and Jamaica now in the Museum of Comparative Zoology; for additional collections Mrs. D. L. Frizzell (Dr. H. Exline) of Rolla, Missouri; Mrs. Frizzell and Dr. E. S. Ross for specimens from the California Academy of Sciences (CAS); Dr. O. Kraus of the Senckenberg Museum, Frankfurt (SMF); and Dr. R. V. Chamberlin for a specimen of the University of Utah collection (UU); Dr. E. Dresco, Paris, for making drawings of Meotipa species; Prof. M. Vachon of the Muséum National d'Histoire Naturelle, Paris (MNHN) ; Prof. G. C. Varley of the Hope Department of Entomology, Oxford, and Dr. G. O. Evans, Mr. E. Browning, and Mr. K. Hyatt of the British Museum, Natural History for their hospitality while visiting their institutions. A. Riedel and J. Prószyński of the Polish Academy of Sciences, Warsaw (PAS); Dr. L. Brundin, Riksmuseum, Stockholm, Mr. T. Yaginuma, Osaka, and Dr. J. V. Scorza, Caracas loaned valuable specimens. A National Science Foundation grant (G-43I7) made possible a trip to Europe to examine types and the National Institute of Health grant (E-I944) facilitated completion of the study and publication of the manuscript.

\section{Chry'sso O. P.-Cambridge}

Chrysso O. P.-Cambridge, 1882, Proc. Zool. Soc. London, p. 429. Type species by original designation Chrysso albomaculata O. P.-Cambridge.

Meotipa Simon, 1892, Histoire Naturelles des Araignées, 1: 519. Type species by original designation Meotipa picturata Simon.

Physcoa Thorell, 1895, Descriptive Catalog of the Spiders of Burma, p. 83. Type species by original designation Physcoa scintillans Thorell.

Argyria Yaginuma, 1957, Acta Arachnologica, 15: 11. Type species by original designation Argyria venusta Yaginuma. Homonym of Argyria Huebner, 1818, and Argyria Robineau-Desvoidy, 1863.

Argyroaster Yaginuma, 1958, Acta Arachnologica, 15: 37. New name for Argyria Yaginuma preoccupied.

Arctachaea Levi, 1958, Psyche, 64: 102. Type species by original designation Arctachaea pelyx Levi.

Diagnosis. Chrysso differs from Theridion by a hump or posterior dorsal extension of the abdomen; from Achaearanea by having a much more complicated palpus containing a radix; from Argyrodes and Spintharus by lacking a colulus (Levi and Levi, I962).

Comments. The types of Chrysso nigriceps Keyserling and Helvibis sulcata Keyserling have been examined since publishing my paper in 
1957. The specimens given those names were correctly identified.

The following species have recently been misplaced in Chrysso: Chrysso maronica Caporiacco, 1954 (Comm. Pontificia Acad. Sci. I6: 74 ) is Achaearanea hirta (Taczanowski). NEW SYNONYMY. $C$, pentagona Caporiacco, 1954, ibid., I6: 75 belongs to Achaearanea.

While many species of Chrysso are strikingly colored, the coloration usually cannot be used for determination or as a key character. As in most theridiids, it is variable, e.g. Chrysso compressa (Keyserling) has a striking black sternum and abdomen with a black venter in Brazil, but the venter is yellow in Peruvian specimens. Uyemura (1957) has observed rapid color change in Chrysso venusta (Yaginuma) when disturbed. Probably other species of Chrysso can also change color.

Species of Chrysso are absent from the United States and Canada except $C$. albomaculata and $C$. clementinae (Map) found in the southeastern states and the two species previously placed in Arctachaea found from Wyoming to Alaska. None are known from Chile or southern Argentina. Most species are found in the hotter parts of America, where the spider fauna is least known, and our knowledge of the species and their distribution is fragmentary.

Key to the American species of Chrysso

Ia. Mesal tip of male cymbium with teeth (1957, figs. II-I3), female chelicerae toothless; Wyoming to Alaska

Ib. Cymbium without teeth; female chelicerae usually with teeth; southeastern United States to South America

2a. Mesal corner of cymbium projecting (1957, figs. 12, 13); female abdomen higher than long

2b. Mesal corner of cymbium rounded (1957, fig. II); female abdomen longer than high .... C. nordica (Chamberlin and Ivie)

3a. Males

3b. Females 25

4a. Thread-shaped portion of embolus originating in center of bulb, looping towards outside and base before continuing straight towards distal end ( 1955 , figs. I-5)

4b. Embolus otherwise

5a. Width of area enclosed by embolus loop almost equals width of basal portion of embolus ( 1955, fig. I 5) ; Huánuco, Peru

5b. Width of area enclosed by embolus loop at least twice width of basal portion of embolus thread (1955, figs. 7, 9, 13) ........... 6

6a. Median apophysis with a large thorn (1955, fig. I3); Amazon, Peru C. sulcata (Keyserling) 
6b. Median apophysis without thorn ..................................... 7

7a. A thorn on ectal side of palpal bulb (1955, figs. 7, 9) …...... 8

7b. No thorn on ectal side of bulb ......................................... 9

8a. Radix with evenly rounded swelling; ectal thorn large (1955, fig. 7) ; Panama ............................................ C. vallensis Levi

8b. Radix with round boss; ectal thorn small (1955, fig. 9) ; Panama, Peru

C. diplosticha Chamberlin and Ivie

9a. Radix with a swelling; conductor almost lanceolate in ventral view (1955, fig. I I) ; coloration as in I955 fig. I2 ; Panama ...

C. indicifer Chamberlin and Ivie

9b. Radix without swelling; conductor hook-shaped ( 1955, fig. I-6) ; coloration otherwise

IOa. Radix with a mesal fold, (1955, figs. I-4); abdomen usually with spots; North Carolina to Brazil

C. albomaculata O. P.-Cambridge

Iob. Radix without fold (1955, figs. 5, 6) ; abdomen without discrete spots; Panama to Argentina ........ C. vexabilis Keyserling

I Ia. Prominent ventral embolus biforked (Figs. 8, I3) ............... I2

I Ib. Embolus otherwise .................................................... I3

I2a. Embolus long, reaching base of bulb (Fig. I3) ; southern Brazil

C. nigrosternum Keyserling

I2b. Embolus short, covering distal two-thirds of bulb (Fig. 8); Minas Gerais

C. gounellei sp. n.

I3a. Distal end of cymbium truncate

I3b. Distal end of cymbium rounded 15

14a. Ventral view as in Fig. I8; southern Barzil

C. perplexa Keyserling

I4b. Ventral view as in Fig. 28; Venezuela C. simoni sp. 11.

15a. With long thread-shaped embolus of even diameter (Fig. 23); Costa Rica to Trinidad C. questona sp. n.

I5b. Embolus otherwise

I6a. Embolus corkscrew-shaped, on distal end of bulb (Figs. 89, 94)

I6b. Embolus otherwise

I7a. Embolus larger than remaining portion of bulb (Fig. 89); abdomen higher than long; Panama to Ecuador .... C. silva sp. n.

I $7 \mathrm{~b}$. Embolus one-third length of remaining portion of bulb (Fig. 95); abdomen longer than high; Costa Rica, Panama

C. volcanensis sp. n.

18a. Embolus with distal portion hook-shaped (Fig. 47); Mexico to Venezuela C. cambridgei (Petrunkevitch)

I8b. Embolus otherwise 
19a. Two transparent sickle-shaped structures on venter of bulb (Fig. 42) ; Colombia to Bolivia ........... C. vittatula (Roewer)

19b. Palpal bulb without sickle-shaped structures ...................... 20

20a. Conductor prominent and with distal hook (Fig. 74); cosmotropical

C. clementinae (Petrunkevitch)

2ob. Conductor otherwise

2ia. Embolus a ventral bottle-shaped structure (Fig. 69); Peru to Brazil C. compressa (Keyserling)

2ib. Embolus otherwise

22a. Median apophysis not apparent in ventral view (Fig. 30); southern Brazil

C. arops sp. n.

22b. Median apophysis visible in ventral view

23

23a. Median apophysis in distal half of bulb, palpus lightly sclerotized (Fig. 79) ; Panama ................................ C. melba sp. n.

23b. Median apophysis mostly on proximal half of bulb; palpus heavily sclerotized

24

24a. Palpus as in Figure 36, 37; Colombia to Bolivia

24b. Palpus as in Figure $5 \mathrm{I}$; Venezuela

C. ecuadorensis Levi

C. barromachadoi Caporiacco

25a. Epigynum with openings in coiled borders of fossa (Fig. 78); Costa Rica to Trinidad ……...................... C. questona sp. n.

25b. Epigynum otherwise 26

26a. Ducts showing through epigynal wall long and coiled, openings indistinct (Figs. 82, 84)

26b. Epigynum otherwise

27a. Ducts loosely coiled in large loops (Fig. 83) ; Panama

C. alecula sp. n.

27b. Ducts tightly coiled (Fig. 85) ; Trinidad

C. arima sp. n.

28a. Epigynum with a central black mark (Fig. 45); sternum, venter black; Mexico to Venezuela .... C. cambridgei (Petrunkevitch)

28b. Epigynum otherwise; sternum and venter usually not black (except $C$. compressa, C. nigrosternum)

29a. Openings of epigynum widely separated (Fig. 88); Panama to Ecuador

C. silva sp. n.

29b. Epigynum otherwise 30

30a. Epigynum with a light, oval swelling, bordered all around (Figs. $34,35,40)$ Colombia to Bolivia $3 \mathrm{I}$

3ob. Epigynum otherwise 32

3ra. A dark mark anterior to swelling (Figs. 34, 35)

3Ib. A dark mark posterior to swelling (Fig. 40)

C. ecuadorensis Levi C. vittatula (Roewer) 
32a. Epigynum with a light swelling bordered anterior and sides (Fig. 50) ; Venezuela C. barromachadoi Caporiacco

32b. Epigynum otherwise 33

33a. Epigynum with openings near posterior margin in a depression, ducts loop anterior (Fig. 54); southern Brazil

C. ribeirao sp. n.

33b. Epigynum otherwise

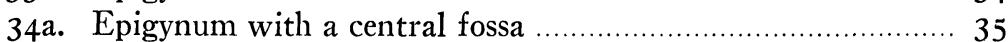

34b. Epigynum without fossa ............................................. 4I

35a. Two openings in center of fossa (Fig. 93) ; Costa Rica, Panama C.volcanensis sp. $\mathrm{n}$.

35b. Epigynum otherwise 36

36a. A black circular mark on each lateral end of fossa (Fig. 73); cosmopolitan

C. clementinae (Petrunkevitch)

36b. Epigynum otherwise

37a. Fossa far anterior, usually bordered on sides only (Fig. 27); Venezuela

C. simoni sp. n.

$37 \mathrm{~b}$. Fossa in center or posterior, bordered anterior or posterior as well as sides

38a. Fossa in a dark spot; ducts visible posterior to fossa (Figs. I6, I7) ; Brazil, Argentina

C. rubrovittata (Keyserling)

38b. Epigynum otherwise

39a. Narrow ducts leading from sides into fossa (Figs. 57, 62) ... 40

39b. Ducts wider and leading from anterior into fossa (Figs. 64, 66, 67), Peru to Brazil

C. compressa (Keyserling)

40a. Fossa bordered on sides and posterior (Fig. 57); southern Brazil ....................................... C. pulchra (Keyserling)

4ob. Fossa bordered on sides and anterior (Fig. 62) ; Minas Gerais ..

C. caraca sp. n.

4Ia. Epigynal openings in a slit anterior to a dark area (Fig. 6o); ducts simple (Fig. 59); San Fernandez Isl.

C. backstromi (Berland)

4I b. Epigynal openings otherwise; usually with internal sacs ........ 42

42a. Epigynum a central transverse connected dark mark as in Figure 2 I ; Brazil

C. antonio sp. n.

42b. Epigynum otherwise

43a. Epigynum with two central dark curved marks (Figs. IO, I2); southern Brazil

C. nigrosternum (Keyserling)

43b. Epigynum otherwise

44a. Epigynum with an anterior dark mark and light posterior as in 1955, fig. 33; head region blackened; Colombia, Ecuador C. nigriceps Keyserling

44b. Epigynum otherwise, coloration usually otherwise 
45a. Epigynum with two lines, diverging posterior (1955, fig. 3I) ; Panama to Peru ............... C. diplosticha Chamberlin and Ivie

45b. Epigynum otherwise ............................................... 46

46a. Epigynum with a transverse dark mark posterior to two spots ( I955, fig. 29) ; Panama .......................... C. vallensis Levi

46b. Epigynum otherwise 47

47a. Epigynum with a transverse line anterior to two spots (1955, fig. 37) ; southern Brazil ................................... C. sicki Levi

47b. Epigynum otherwise 48

48a. Epigynum with a pair of longitudinal lines in light area posterior to transverse dark mark (1955, fig. 35) ; dorsum of abdomen with two black long lines which fuse at posterior end; Panama C. indicifer Chamberlin and Ivie

48b. Epigynum otherwise 49

49a. Carapace dark brown; abdomen with a longitudinal dark band ( I955, fig. 20) ; Peru C. huanuco Levi

49b. Coloration otherwise 50

50a. Abdomen without discrete white spots; Panama to Argentina C. vexabilis Keyserling 5ob. Abdomen usually with white spots; North Carolina to Brazil C. albomaculata O. P.-Cambridge

\section{Chrysso albomaculata O. P.-Cambridge}

Argyrodes elegans Taczanowski, 1872, Horae Soc. Ent. Rossicae, 9: 118, pl. 5, fig. 11, ㅇ. Female syntypes from Uassa, French Guiana [now Rio Uaçá, Amapa, Brazil] in the Polish Academy of Sciences, Warsaw, examined. NEW SYNONYMY. Not Theridion elegans Blackwall, 1862.

Chrysso albomaculata O. P.-Cambridge, 1882, Proc. Zool. Soc. London, p. 429, fig. 6 , $9, \hat{\delta}$. Male, female syntypes from the Amazon in the Hope Department of Entomology, Oxford, examined. - Levi, 1955, Jour. New York Ent. Soc., 68 : 61, figs. 1-4, 18-19, 25-27, 우, ô.

Chrysso elegans, - Keyserling, 1884, Die Spinnen Amerikas, Theridiidae 2 (1) : 151.

Theridion elegans, - Simon, 1903, Histoire Naturelle des Araigneés, 2: 990.

Theridion emendatum Roewer, 1942, Katalog der Araneae 1: 429. New name for Argyrodes elegans 'Taczanowski. NEW SYNONYMY.

Distribution. Southeastern United States, Mexico, West Indies, northeastern South America to Bahia, Brazil.

Additional records. Lesser Antilles. Grenada: St. George's (N. L. H. Krauss, AMNH). Trinidad: Mt. St. Benedict (J. G. Myers). Venezuela. Carabobo: San Esteban, I888 (E. Simon, MNHN). Grand Elang. Dist. Fed.: hacienda Corosal, N of Mt. Silla, I 888 (E. Simon, MNHN). British Guiana. Georgetown (A. M. Nadler, AMNH). Surinam. Paramaribo. Brazil. Ceara: Sierra Com- 
munaty (E. Gounelle, MNHN). Pernambuco: Recife (SMF; A. M. Nadler, AMNH). Bahia: Salvador (A. M. Nadler, AMNH); Terra Nova (MNHN).

\section{Chrysso vexabilis Keyserling}

Chrysso vexabilis Keyserling, 1884, Die Spinnen Amerikas, Theridiidae, $2(1)$ : 155, pl. 7, fig. 96, + , $\hat{o}$. Syntypes from N. Granada [now Ecuador, Colombia, Panama, Venezuela] in the British Museum, Natural History, examined. - Levi, 1955, Jour. New York Ent. Soc., 63: 63, figs. 5, 6, 23, 24, ㅇ, $\hat{o}$.

Steatoda rubicunda F. P.-Cambridge, 1902, Biologia Centrali-Americana, Araneidea, 2: 386, pl. 36, fig. 21, ô. Male type from Bugaba, Panama in the British Museum, Natural History, examined. (Not Theridion rubicunda Nicolet, 1849.) NEW SYNONYMY.

Theridion rubicundulum Roewer, 1942, Katalog der Araneae, 1: 498. New name for Theridion rubicunda (F. P.-Cambridge). NEW SYNONYMY.

Examination of Keyserling's type indicated that this species had been correctly determined. The internal female genitalia of Argentine specimens like the ones from Panama, have the posterior portion of the sacs of the internal genitalia ending in narrow extensions (Levi, I955, fig. 23) quite different from the broadly rounded sacs of $C$. albomaculata. Unlike $C$. albomaculata it has no white spots on abdomen.

Distribution. Panama to Argentina.

Additional records. Venezuela. Dist. Fed.: hacienda Corosal, o, $\sigma^{\top}$ (E. Simon, MNHN). Ecuador. Guayas: Milagro, 우, o (H. E., D. L. Frizzell) ; Río Chimbo, ơ (Edwards, MNHN). El Oro: Arenillas (E. L. Moore). Brazil. Bahia: Salvador, \&, (E. Göldi, MNHN); Rio Salobro, o (E. Gounelle, MNHN, doubtful det.). Argentina. Córdoba: Cosquín, 우.

\section{Chrysso diplosticha Chamberlin and Ivie}

Chrysso diplosticha Chamberlin and Ivie, 1936, Bull. Univ. Utah, biol. ser., 3 (5) : 36, fig. 83, 9 . Female type from Barro Colorado Island, Panama Canal Zone in the University of Utah Collection. - Levi, 1955, Jour. New York Ent. Soc., 63: 65, figs. 9, 30, 31, ㅇ, $\hat{0}$. Peru.

Distribution. Nicaragua, Panama, Trinidad and Dept. Huánuco,

Additional records. Nicaragua: Musawas, Waspuc River, $\sigma^{\top}$ (B. Malkin, AMNH). Lesser Antilles. Trinidad: Simla near Arima, б’ (A. M. Nadler, AMNH).

\section{Chrysso indicifer Chamberlin and Ivie}

Chrysso indicifer Chamberlin and Ivie, 1936, Bull. Univ. Utah, biol. ser., $3(5): 36$, figs. $82,96,9$. Female type from Barro Colorado Island in the 
University of Utah collection. - Levi, 1955, Jour. New York Ent. Soc., $63: 66$, figs. $11,12,17,34,35$, 우 , ô.

Distribution. Panama to Peru.

Additional records. Venezuela. Dist. Fed. Caracas, (E. Simon, MNHN). Carabobo: La Cumbre, S. of San Esteban, (E. Simon, MNHN). Ecuador. Guayas: Milagro, (H. E., D. L. Frizzell) ; Río Chimbo, (MNHN). El Oro: Arenillas, (E. L. Moore) ; Pasaje, (R. Walls). Peru. Huánuco: Monzón Valley, Tingo María, 우 ơ (E. I. Schlinger, E. S. Ross, CAS).

\section{Chrysso gounellei sp. n.}

Figures 6-8

Type. Male from Caraça, Minas Gerais, Brazil (E. Gounelle), in the Muséum National d'Histoire Naturelle, Paris (no. 9487). The species is named after E. Gounelle who collected for E. Simon.

Description. Carapace orange, eye region black. Sternum black. Legs yellowish to gray. Abdomen white with two black spots above spinnerets (Fig. 7), sometimes also with a pair of anterior spots. Carapace low and flat. Anterior median eyes larger than others, one and one-third their diameter apart, three-quarters from laterals. Posterior median eyes one and one-quarter their diameter apart, one and one-half from laterals. Chelicerae with three teeth on anterior margin, the middle one smallest, five sharp teeth posterior (Fig. 6). Abdomen longer than wide with indistinct grooves on sides (Fig. 7). Total length $1.9 \mathrm{~mm}$. Carapace $1.0 \mathrm{~mm}$ long, $0.8 \mathrm{~mm}$ wide. First femur, I.I mm; patella and tibia, I.I $\mathrm{mm}$; metatarsus, $0.9 \mathrm{~mm}$; tarsus, $0.5 \mathrm{~mm}$. Second patella and tibia, $0.9 \mathrm{~mm}$; third, $0.6 \mathrm{~mm}$; fourth, $0.9 \mathrm{~mm}$.

Diagnosis. The two prongs of the embolus (Fig. 8) of $C$. gounellei are shorter than those of the related C. nigrosternum (Keyserling).

Record. 6 paratypes collected with holotype.

\section{Chrysso nigrosternum Keyserling}

Figures 9-I3

Theridium rotundum Keyserling, 1891, Die Spinnen Amerikas, Brasilianische Spinnen, 3: 191, pl. 6, fig. 137, + . Female type from N. Freiburg [Nova Friburgo, Est. Guanabara], Brazil in the British Museum, Natural History, examined. NEW SYNONYMY.

Chrysso nigrosternum Keyserling, 1891, Die Spinnen Amerikas, Brasilianische Spinnen, 3: 206, pl. 7, figs. 148, + , $\hat{o}$. Female, male syntypes from Taquara do Mundo Novo, [Rio Grande do Sul], Brazil in the British Museum, Natural History, examined. The female syntype is in poor condition. 
Note. The similarity of my illustrations of the female types of the two names was not noted until some time after the examination. Keyserling's descriptions, except for the color of the abdomen, are also similar. Although rotundum has page priority, the name Chrysso nigrosternum Keyserling is used here, because the male palpus is very distinct while the epigyna are not. Figures I I, I 2 were made from the type of $T$. rotundum, Figures 9, IO, I 3 from those of $C$. nigrosternum.

\section{Chrysso rubrovittata (Keyserling), new combination} Figures I4-I 7

Faiditus rubrovittatus Keyserling, 1884, Die Spinnen Amerikas, Theridiidae, 2(1): 159, pl. 7, fig. 98, o. Female type without locality in the Hope Department of Entomology at Oxford University, examined. It probably came from South America.

Faiditus lacteovittatus Mello-Leitão, 1945, Rev. Museo La Plata, nueva serie, sec. Zool., 4: 233, fig. 7. Female type from Puerto Victoria, Missiones, Argentina in the La Plata Museum, examined. NEW SYNONYMY.

Description. Female from Pernambuco. Carapace, sternum, legs yellow. Abdomen grayish white with a dorsal, longitudinal white band and some white pigment spots (Fig. I4). Eyes subequal in size. Anterior median eyes one and one-half diameters apart, their radius from laterals. Posterior median eyes one and one-half diameters apart, their radius from laterals. Chelicerae with two teeth on anterior margin. Abdomen without lateral grooves (Fig. I4). Epigynum with central, sclerotized opening having a posterior lip (Figs. I6, I7). Total length $3.9 \mathrm{~mm}$. Carapace I. I mm long, I.02 mm wide. First femur 2.10 $\mathrm{mm}$; patella and tibia $\mathrm{I} .95 \mathrm{~mm}$; metatarsus $1.62 \mathrm{~mm}$; tarsus $0.78 \mathrm{~mm}$. Second patella and tibia $\mathrm{I} . \mathrm{I} 7 \mathrm{~mm}$; third $0.75 \mathrm{~mm}$; fourth $1.30 \mathrm{~mm}$.

Explanation of Plate 14

Figs. 1, 2. Chrysso nigra (O. P.-Cambridge) (Ceylon). 1. Left palpus. 2. Epigynum cleared.

Figs. 3-5. C. venusta (Yaginuma) (Japan). 3. Female genitalia, dorsal view. 4. Epigynum. 5. Palpus.

Figs. 6-8. C. gounellei sp. n. 6. Male left chelicera, posterior view. 7 . Abdomen, dorsal view. 8. Palpus.

Figs. 9-13. C. nigrosternum Keyserling. 9, 11. Female genitalia, dorsal view. 10, 12. Epigynum. 13. Palpus.

Figs. 14-17. C. rubrovittata (Keyserling). 14. Female abdomen, lateral view. 15. Female genitalia, dorsal view. 16, 17. Epigynum.

Fig. 18. C. perplexa Keyserling. Palpus.

Figs. 19-21. C. antonio sp. n. 19. Female abdomen, lateral view. 20. Female genitalia, dorsal view. 21. Epigynum.

Figs. 22, 23. C. questona sp. n. palpus. 22. Mesal view. 23. Ventral view.

Figs. 24-28. C. simoni sp. n. 24. Female abdomen, lateral view. 25. Female genitalia, dorsal view. 26. Epigynum cleared. 27. Epigynum. 28. Palpus. 

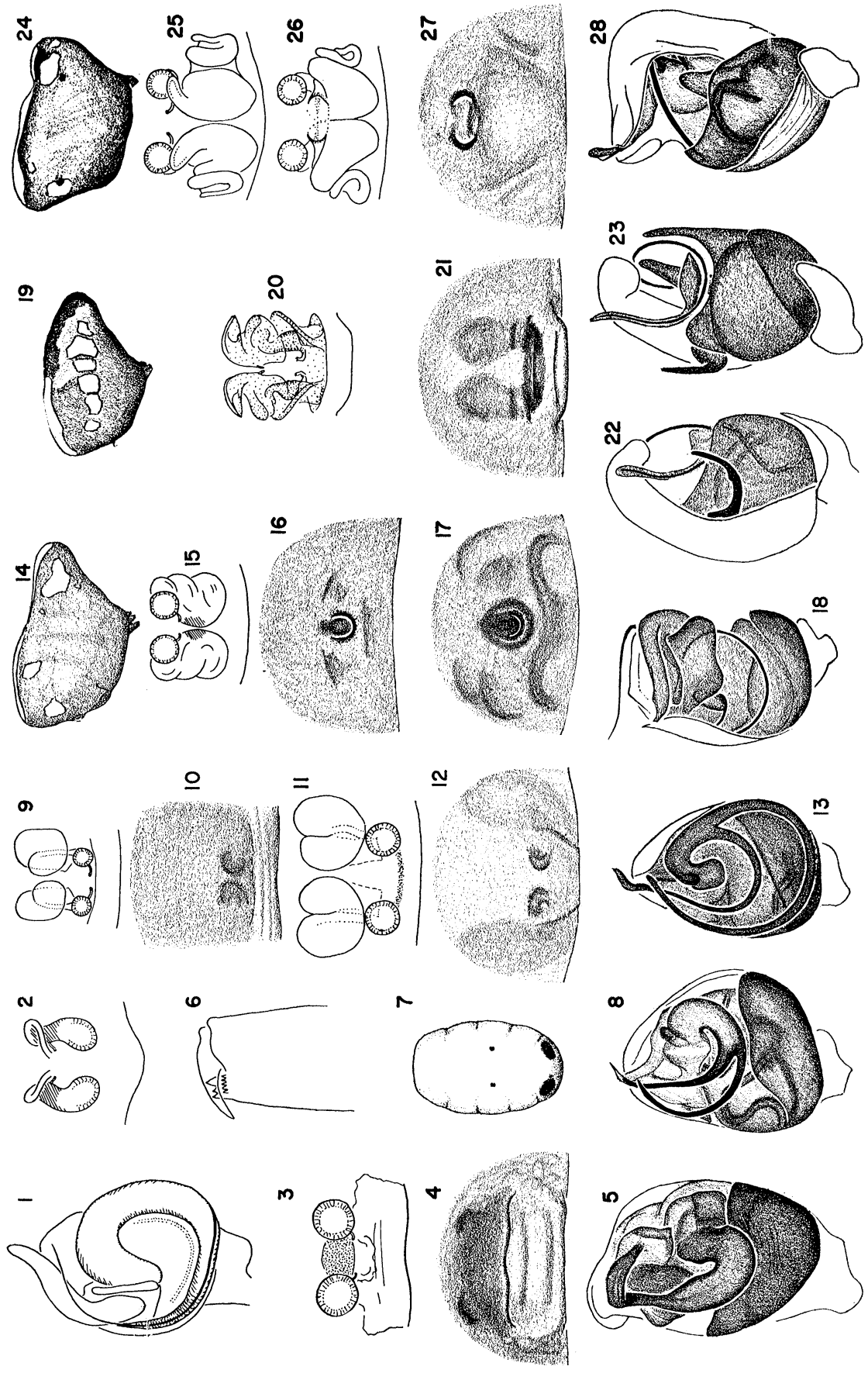
Figures 15, I6 were made from the type of Faiditus rubrovittatus. Distribution. Brazil, Argentina.

Record. Brazil. Pernambuco: Recife, o (SMF); Minas Gerais: Caraça, o (E. Gounelle, MNHN).

\section{Chrysso perplexa Keyserling}

Figure I 8

Chrysso perplexa Keyserling, 1886, Die Spinnen Amerikas, Theridiidae, 2(2): 242, pl. 20, fig. 296, $\hat{o}$. Male type from Blumenau, [Santa Catarina], Brazil in the British Museum, Natural History, examined. Figure 18 was prepared from the type.

Record. Brazil. Santa Catarina: Nova Teutonia, lat $27^{\circ}$ I I' S, long $52^{\circ} 23^{\prime} \mathrm{W}, 0^{\top}$ (F. Plaumann, SMF).

\section{Chrysso antonio sp. $n$}

Figures 19-2 I

Type. Female from São Antonio de Barro [Condeúba, Bahia], Brazil (E. Gounelle), in the Muséum National d'Histoire Naturelle, Paris (no. I 15I8). The specific name is a noun in apposition after the type locality.

Description. Carapace dark brown, dusky on sides. Chelicerae, sternum black. Legs yellowish. Abdomen with dorsal white patch and five white spots on sides on gray background a darker, indistinct gray band behind dorsal white spot continuing to a black posterior tip (Fig. I9). Eyes subequal in size. Anterior median eyes one diameter apart, their radius from laterals. Posterior eyes their diameter apart. Chelicerae with two long teeth on anterior margin. Abdomen without grooves (Fig. I9). Total length $2.5 \mathrm{~mm}$. Carapace $0.85 \mathrm{~mm}$ long, $0.65 \mathrm{~mm}$ wide. First femur, I.20 mm; patella and tibia, 0.98

\section{Explanation of Plate 15}

Figs. 29-30. Chrysso arops sp. n. 29. Male abdomen, lateral view. 30. Left palpus.

Figs. 31-37. C. ecuadorensis Levi. 31, 32. Female abdomen, lateral view. 33. Female genitalia, dorsal view. 34, 35. Epigynum. 36, 37. Palpus. 36. Mesal view. 37. Ventral view.

Figs. 38-42. C. vittatula (Roewer). 38. Female abdomen, lateral view. 39. Female genitalia, dorsal view. 40. Epigynum. 41, 42. Palpus. 41. Mesal view. 42. Ventral view.

Figs. 43-47. C. cambridgei (Petrunkevitch). 43. Female, lateral view. 44. Female genitalia, dorsal view. 45. Epigynum. 46. Palpus expanded, mesal view (cymbium removed; C, conductor; E, embolus; M, median apophysis; $R$, radix $)$. 47. Palpus.

Figs. 48-51. C. barromachadoi Caporiacco. 48. Abdomen of juvenile, lateral view. 49. Female genitalia, dorsal view. 50. Epigynum. 51. Palpus. 
Psyche, 1962

Vol. 69, Plate 15
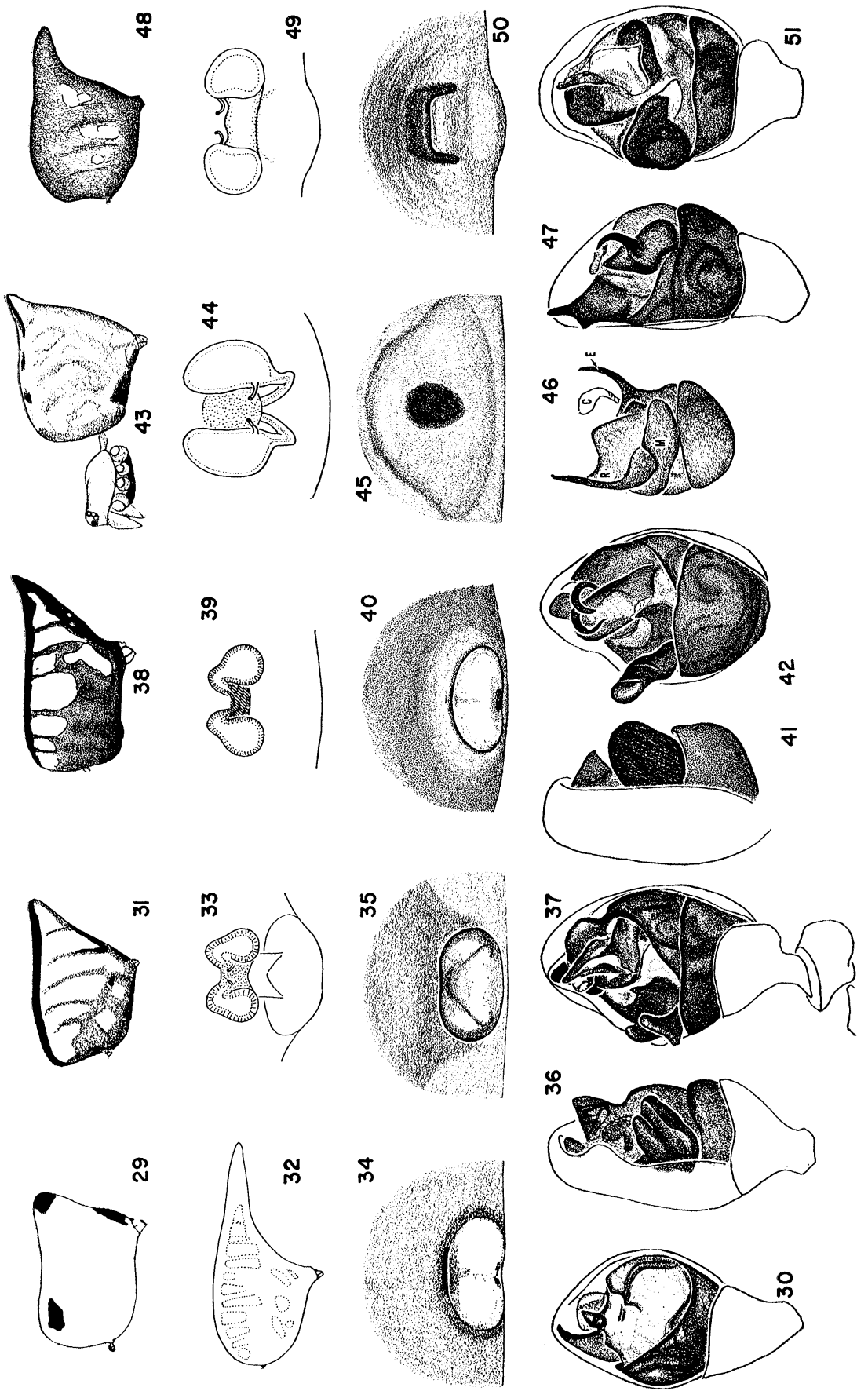
$\mathrm{mm}$; metatarsus, $0.78 \mathrm{~mm}$; tarsus, $0.50 \mathrm{~mm}$. Second patella and tibia, $0.71 \mathrm{~mm}$; third, $0.52 \mathrm{~mm}$; fourth, $0.91 \mathrm{~mm}$.

Diagnosis. The epigynum, which has a dark patch in a light transversely folded area (Fig. 2I), separates this species from $C$. albomaculata. The sacs of the internal genitalia (Fig. 20) are more complex in shape than in related species.

\section{Chrysso questona sp. n.}

Figures 22, 23, 76-78

Type. Female from El Valle, Panama, July I936 (A. M. Chickering), in the Museum of Comparative Zoology. The specific name is an arbitrary combination of letters.

Description. Carapace, sternum, legs whitish. Legs with black rings on middle and distal ends of segments. Abdomen whitish with some black patches (Fig. 76). Chelicerae with two anterior teeth. Anterior median eyes one and one-fourth diameters apart, threefourths from laterals. Posterior median eyes slightly more than a diameter apart, one diameter from laterals. Eyes of male smaller and slightly farther apart. Legs very long. Total length of female $4.5 \mathrm{~mm}$. Carapace $1.3 \mathrm{~mm}$ long, $1.0 \mathrm{~mm}$ wide. First femur, $4.9 \mathrm{~mm}$; patella and tibia, $4.5 \mathrm{~mm}$; metatarsus, $4.9 \mathrm{~mm}$; tarsus $\mathrm{I} .4 \mathrm{~mm}$. Second patella and tibia, $2.3 \mathrm{~mm}$; third, I.2 mm; fourth, $2.0 \mathrm{~mm}$. Total length of male $3.0 \mathrm{~mm}$. Carapace, r. $6 \mathrm{~mm}$ long. Second patella and tibia, 2.7 $\mathrm{mm}$; third, I. $3 \mathrm{~mm}$; fourth, $2.3 \mathrm{~mm}$.

Diagnosis. The coiled rim of the epigynum (Fig. 78), the coiled ducts (Fig. 77) and the long embolus and narrow cymbium (Figs. 22, 23) distinguish this species from $C$. volcanensis.

Records. Costa Rica. San Isidro del General, 600-1200 m, 우 (D. Rounds). Panama: Chiriquí Prov., I938, ô (UU). Trinidad: Simla, 29, 30 Dec. 1954, ; 26 Feb. 1954, ㅇ (A. M. Nadler, AMNH).

\section{Chrysso simoni sp. $n$.}

Figures 24-28

Type. Male from Caracas, Venezuela, December I 887 to February I 888 (E. Simon), in the Muséum National d'Histoire Naturelle, Paris (no. 16392). The species is named after the great araneologist E. Simon.

Description. Carapace yellow-brown, slightly darker in cephalic region. Sternum, legs yellow-brown. Abdomen gray with variable white, darker gray or black patches. Some specimens have a median 
dorsal white longitudinal band, in others the band is almost black (Fig. 24). Eyes subequal in size. Anterior median eyes about one and two-thirds diameter apart, three-quarters from laterals. Posterior median eyes less than two diameters apart, one from laterals. Anterior median eyes of male slightly farther apart than in female. Chelicerae with two teeth on anterior margin, none on posterior. Abdomen longer than wide or high, with posterior tip of female overhanging (Fig. 24) but posterior tip of male more blunt. Total length of female 3.1 $\mathrm{mm}$. Carapace I.I mm long, I.O mm wide. First femur, $2.2 \mathrm{~mm}$; patella and tibia, $2.0 \mathrm{~mm}$; metatarsus, $1.9 \mathrm{~mm}$; tarsus, $0.8 \mathrm{~mm}$. Second patella and tibia $\mathrm{I} .3 \mathrm{~mm}$; third $0.9 \mathrm{~mm}$; fourth $\mathrm{I} .4 \mathrm{~mm}$. Total length of male $2.5 \mathrm{~mm}$. Carapace I.I $\mathrm{mm}$ long, $0.9 \mathrm{~mm}$ wide. First femur, $2.2 \mathrm{~mm}$; patella and tibia, $2.0 \mathrm{~mm}$; metatarsus, $\mathrm{I} .9 \mathrm{~mm}$; tarsus, $0.8 \mathrm{~mm}$. Second patella and tibia, I. $3 \mathrm{~mm}$; third, $0.8 \mathrm{~mm}$; fourth, $\mathrm{I} .3 \mathrm{~mm}$.

Diagnosis. The palpus of the male (Fig. 28) is quite similar to that of $C$. perplexa Keyserling but can be separated from the latter by the shape and length of the embolus, the base of which lies against the alveolus of the cymbium. The internal female genitalia have a lateral duct loop (Figs. 25, 26) unlike that of the related C. rubrovittata (Keyserling). The internal genitalia are asymetrical in the specimens examined.

Records. $3 \sigma^{\pi}$ and 3 q paratypes from type collection.

\section{Chrysso barromachadoi Caporiacco}

Figures 48-5 I

Chrysso barromachadoi Caporiacco, 1955, Acta Zool. Venezuelica, 1: 337. Juvenile type from Rancho Grande, Aragua, Venezuela, in the Museum at Caracas, examined.

Description. Carapace, sternum dark brown. Legs yellow. Abdomen gray to black with white patches on sides of temale (Fig. 48) but lacking in male. Anterior median eyes slightly smaller than others, one and one-half diameters apart, two from laterals. Posterior median eyes one diameter apart one and one-half from laterals. Anterior eyes are slightly closer in male. Abdomen with lateral grooves; female abdomen extension, two-thirds length of abdomen between spinnerets and pedicel. Male abdomen blunt and short. This species can be diagnosed by the genitalia (Figs. 49-5 I).

Figure 48 was made from the juvenile type specimen.

Records. Venezuela. Aragua: Rancho Grande, March 1945; 20 Dec. 1954 (A. M. Nadler, AMNH); Choroní, 9 March 1959, (A. 
M. Nadler, AMNH) ; Carabobo: Le Cumbre, S of San Esteban, I888 (E. Simon, MNHN).

\section{Chrysso cambridgei (Petrunkevitch), new combination Figures 43-47}

Achaea vittata O. P.-Cambridge, 1894, Biologia Centrali-Americana, Araneidea, 1: 130, pl. 17, fig. 11, + . Female type from Teapa, [Tabasco, Mexico] in the British Museum, Natural History, examined. Not Argyrodes vittata Keyserling, Theridion vittatum Nicolet.

Thwaitesia vittata, - O. P.-Cambridge, 1896, op. cit., p. 197.

Thwaitesia lepida O. P.-Cambridge, 1896, op. cit., p. 197, pl. 25, fig. 5, ㅇ․ Female type from Teapa, [Tabasco, Mexico] in the British Museum, Natural History, examined.

Chrysso splendida Banks, - 1898, Proc. California Acad. Sci., (3) 1: 237, pl. 14, fig. 13, o. Female syntype from Tepic, Nayarit, Mexico in the Museum of Comparative Zoology, examined.

Theridion vittatum, - F. P.-Cambridge, 1902, Biologia Centrali-Americana, Araneidea, 2: 391, pl. 37, figs. 6, 7, ఢ, $\hat{0}$.

Theridion splendidum, - F. P.-Cambridge, 1902, op. cit., p. 391.

Theridion cambridgei Petrunkevitch, 1911, Bull. Amer. Mus. Nat. Hist., 29: 192. New name for Achaea vittata thought preoccupied by Theridion vittatum Nicolet and for Thwaitesia lepida thought preoccupied by Theridion lepidum Walckenaer. Reimoser, 1939, Ann. Naturhist. Museum Wien, 50: 346. Roewer, 1943, Katalog der Araneae, 1: 490. Kraus, 1955, Abhandl. Senckenbergischen Naturf. Gesell. 493:17.

Theridion splendens Roewer, 1942, op. cit. p. 498. New name for Chrysso splendida thought preoccupied by Theridion splendidum Taczanowski.

Conopistha acuminata Schenkel, 1953, Verh. Naturf. Gesell. Basel, 64: 12, fig. 12, 9 . Two female syntypes from El Pozon, Venezuela in the Naturhistorisches Museum, Basel, examined. NEW SYNONYMY.

Comments. F. P.-Cambridge first suspected that Bank's splendida is a synonym of vittata. The epigynum, a shallow black depression (Fig. 45) sometimes has an anterior lip. The only male examined was caught in December at Barro Colorado Island by Dr. A. M. Chickering.

Distribution. Mexico to Venezuela.

Records. Mexico. Veracruz: $16 \mathrm{~km} \mathrm{~S}$ of San José del Carmen (L. I. Davis, AMNH). Tabasco: $3 \mathrm{~km} \mathrm{NE}$ of Comalcalco (G. Ekholm). Guatemala: Variedades, $300 \mathrm{~m}$ (C., P. Vaurie, AMNH). El Salvador. (Kraus, 1955). Costa Rica. (Reimoser, 1938). Panama: El Valle. Panama Canal Zone: Barro Colorado Island (sev. collections).

\section{Chrysso vittatula (Roewer), new combination Figures $38-42$}

Argyrodes vittatus Keyserling, 1884, Die Spinnen Amerikas, Theridiidac, 2(1) : 191, pl. 9, fig. 114, 9 . Female syntypes from St. Fe de Bogota [Bogotá, Colombia] and female, male syntypes from Pumamarca, 
[Junín], Peru in the British Museum, Natural History, examined.

Homonym of $A$. vittatus Bradley, 1877.

Argyrodes vittatula Roewer, 1942, Katalog der Araneae, 1: 439. New name for $A$. vittatus Keyserling.

Description. Carapace, sternum dark brown, legs yellow. Abdomen with a longitudinal dorsal black band, series of white patches on sides and venter partly black. Eyes subequal in size. Anterior median eyes one and one-half diameters apart, almost two from laterals. Posterior median eyes one diameter apart, one and one-half from laterals. Chelicerae with two teeth on anterior margin. Total length of female 6.7 $\mathrm{mm}$. Carapace $\mathrm{I} .6 \mathrm{~mm}$ long, I.2 $\mathrm{mm}$ wide. First femur $3.5 \mathrm{~mm}$ long; patella and tibia $3.4 \mathrm{~mm}$ long; metatarsus $3.0 \mathrm{~mm}$ long; tarsus I.I $\mathrm{mm}$. Second patella and tibia $\mathrm{I} .8 \mathrm{~mm}$; third $\mathrm{I} .2 \mathrm{~mm}$; fourth $2.3 \mathrm{~mm}$.

It is uncertain if females have been correctly separated from $C$. ecuadorensis. Females of $C$. vittatula have a dark spot posterior in the light area of the epigynum (Fig. 4O). No other differences were noted. The male palpi, however, are very distinct (Figs. 4I, 42). Only the availability of larger collections will permit finding characters separating the females. Illustrations were made from the syntypes.

Distribution. Colombia to Bolivia.

Records. Peru. Junín: Pumamarca, ㅇ, ox (PAS). Cuzco: San Miguel, o (H. W. Foote). Bolivia: Tunari-Massiv, $4000 \mathrm{~m}, 1948$, o (Zischka, AMNH).

\section{Chrysso ecuadorensis Levi}

Figures 3I-37

Chrysso ecuadorensis Levi, "1955" (1957) Jour. New York Ent. Soc. 63 : 66, figs. 16, 38, 39, 9 . Female type from Runtun Trail, Baños, [Tungurahua], Ecuador in the American Museum of Natural History.

Description. Carapace, sternum red-brown. Legs yellow with ends of first tibiae and all tarsi darker to brown. Abdomen with white patches on sides and above spinnerets and with some black pigment in a median dorsal longitudinal line and above spinnerets (Figs. 3I, 32). Posterior median eyes slightly larger than other eyes. Anterior median eyes one and one-half diameters apart, two from laterals in female, slightly more than two in male. Posterior median eyes one diameter apart, one and three-quarters from laterals in female; in male one and one-quarter diameters apart, two and one-half from laterals. Chelicerae with two teeth on anterior margin, apparently none posterior. Total length of female from Bolivia $5.5 \mathrm{~mm}$. Carapace 1.7 $\mathrm{mm}$ long, I.3 mm wide. First femur, $3.9 \mathrm{~mm}$; patella and tibia, 3.6 $\mathrm{mm}$; metatarsus, $3.6 \mathrm{~mm}$; tarsus, I.2 $\mathrm{mm}$. Second patella and tibia, I.9 mm; third, $1.3 \mathrm{~mm}$; fourth, $2.5 \mathrm{~mm}$. Total length of male from 
Bolivia $4.0 \mathrm{~mm}$. Carapace $1.7 \mathrm{~mm}$ long, $\mathrm{I} .4 \mathrm{~mm}$ wide. First femur, $3.7 \mathrm{~mm}$; patella and tibia, $3.5 \mathrm{~mm}$; metatarsus, $4.2 \mathrm{~mm}$; tarsus, $\mathrm{I} .2$ $\mathrm{mm}$. Second patella and tibia, $2.1 \mathrm{~mm}$; third, $1.4 \mathrm{~mm}$; fourth, 2.3 $\mathrm{mm}$.

Diagnosis. It is not certain whether females have been correctly separated from $C$. vittatula Roewer. The light area of the epigynum has a dark spot anterior (Figs. 34, 35). Only large collections of accompanied females will make the separation of the species possible.

Distribution. Colombia to Bolivia.

Records. Colombia. Cauca: $43 \mathrm{~km} \mathrm{~S} \mathrm{Popayán,} \mathrm{March} \mathrm{i955,} \mathrm{우}$ (E. I. Schlinger, E. S. Ross, CAS). Ecuador. Los Rios: Macuchi, copper mining camp inland from Río Palenque, March, I943 + ( $\mathrm{H}$. E. Frizzell). Tungurahua: Mt. Tungurahua, I900-2000 m, Apr. 1939, o (W. C. Macintyre) ; Baños, I850-2000 m, Apr. I939, o (W. C. Macintyre, AMNH). Bolivia. Chaco, $2000 \mathrm{~m}$, 우, ơ (MNHN).

\section{Chrysso compressa (Keyserling), new combination Figures 63-70}

Achaea compressa Keyserling, 1882, Die Spinnen Amerikas. Theridiidae, 2(1): 107, pl. 5, fig. 69, + . Female type from Amable María, [Junín], Peru in the Polish Academy of Sciences, Warsaw.

Theridion conspersa, - Simon, 1894, Histoire Naturelle des Araignées, 1: 535 (misspelling).

Theridion compressum, - Roewer, 1942, Katalog der Araneae, 1: 491.

Comments. A specimen, presumably collected with the type, in the British Museum, Natural History, was examined. The abdomen resembles $C$. cambridgei, it has slight grooves on sides; a black band covers dorsum.

Description. Carapace yellow-white, yellowish in head region. Sternum yellow in Peruvian specimens, black in Brazilian. Legs yellow-white, distal ends of most leg segments darker yellow with denser, darker hairs. Abdomen with median dorsal colorless area and with white pigment on each side. Brazilian specimens have genital area

Explanation of Plate 16

Figs. 52-54. Chrysso ribeirao sp. n. 52. Female abdomen, lateral view. 53. Female genitalia, dorsal view. 54. Epigynum.

Figs. 55-57. C. pulchra (Keyserling). 55. Female abdomen, lateral view. 56. Female genitalia, dorsal view. 57. Epigynum.

Figs. 58-60. $C$. backstromi (Berland). 58. Female. 59. Female genitalia, dorsal view. 60. Epigynum. num.

Figs. 61, 62. C. caraca sp. n. 61. Female genitalia, dorsal view. 62. Epigy-

Figs. 63-70. C. compressa (Keyserling). 63, 65. Female genitalia, dorsal view. 64, 66, 67. Epigynum. 68. Female abdomen, lateral view. 69, 70. Left palpus. 

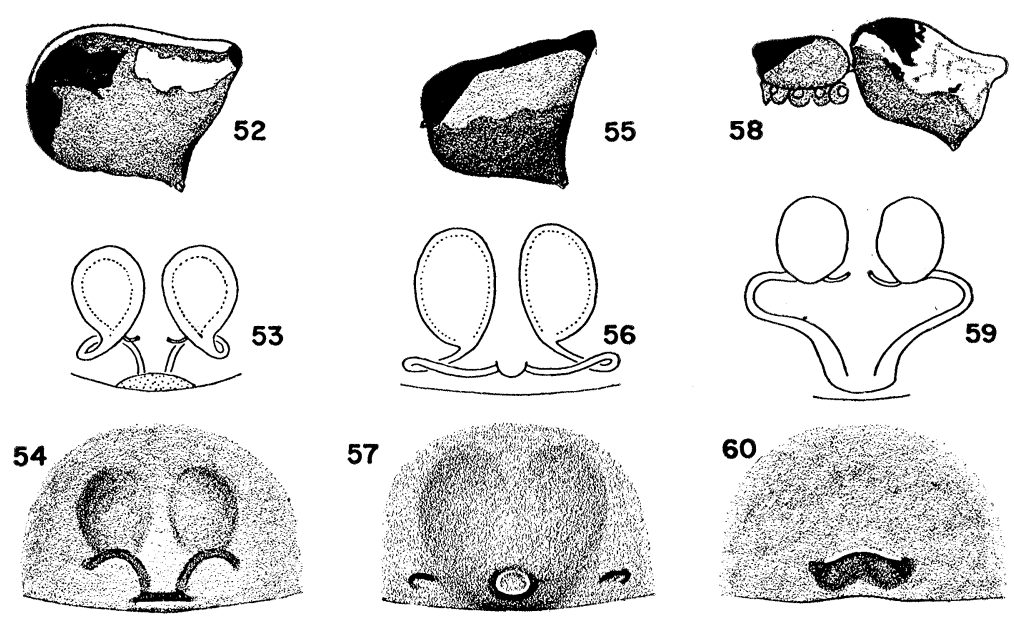

57

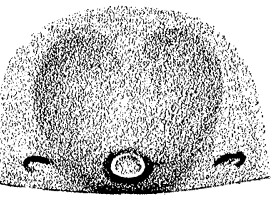

60
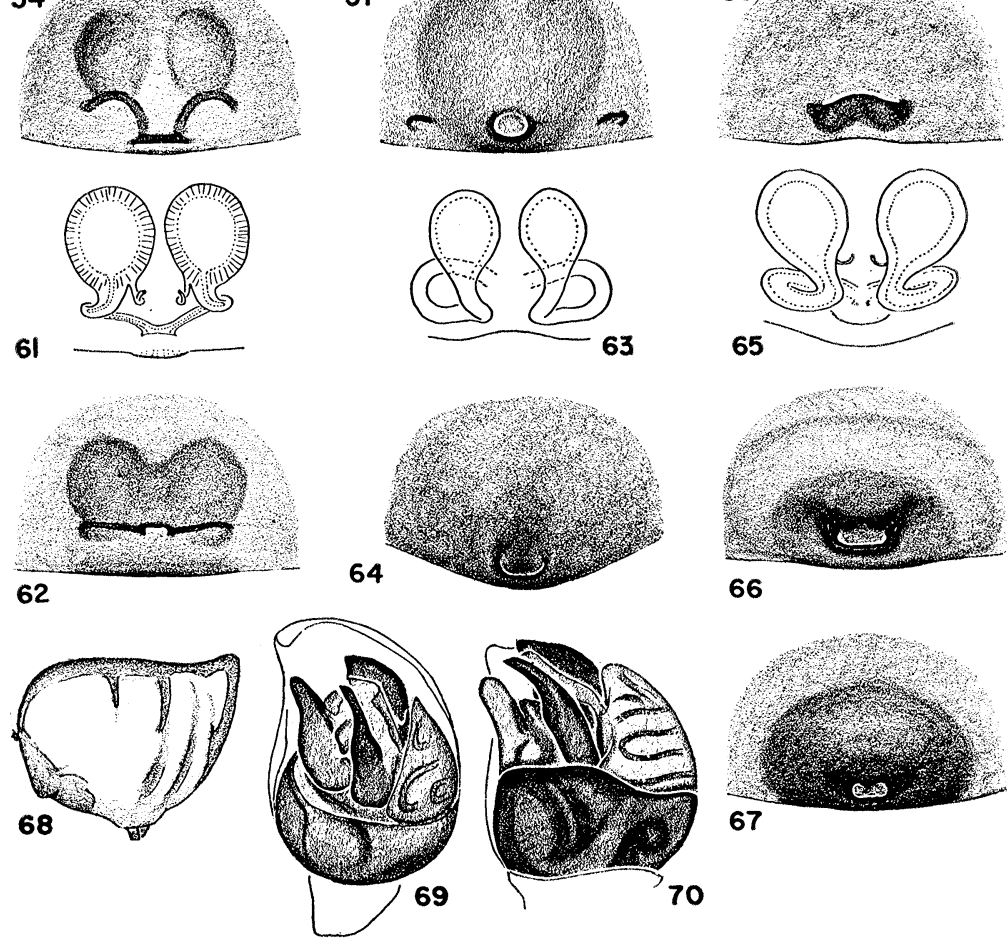

66

$$
\text { Levi - Chrysso }
$$

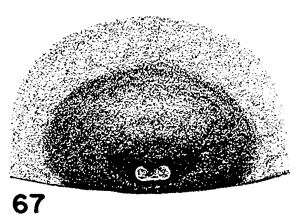


black and a black spot anterior to spinnerets. Anterior median eyes slightly larger than others or subequal, their diameters apart, and onethird from laterals. Posterior median eyes slightly oval, their shorter diameter apart, and one and one-half from laterals. Chelicerae with two teeth on anterior margin. Abdomen usually without grnoves. Total length of female from Peru 6.I mm. Carapace $1.8 \mathrm{~mm}$ long, I.4 $\mathrm{mm}$ wide. First femur $5.4 \mathrm{~mm}$; patella and tibia $5.4 \mathrm{~mm}$; metatarsus 5.5 ; tarsus $1.8 \mathrm{~mm}$. Second patella and tibia $3.0 \mathrm{~mm}$; third $\mathrm{r} .8$ $\mathrm{mm}$; fourth $3.2 \mathrm{~mm}$. Total length of male from Brazil 4.I $\mathrm{mm}$. Carapace $1.7 \mathrm{~mm}$ long. First femur 6.1 mm; patella and tibia 6.I $\mathrm{mm}$; metatarsus $3.6 \mathrm{~mm}$; tarsus $\mathrm{I} .8 \mathrm{~mm}$. Second patella and tibia 3.3 $\mathrm{mm}$; third $\mathrm{x} .8 \mathrm{~mm}$; fourth $3.3 \mathrm{~mm}$.

The shape of the epigynum fossa is variable (Figs. 64, 66, 67). Figures 63, 64 were prepared from the types.

Distribution. Peru to southeastern Brazil.

Records. Peru. San Martín: Mishqui-yacu, $1600 \mathrm{~m}, 20 \mathrm{~km} \mathrm{NE}$ of Moyobamba, Aug. 1947, + (F. Woytkowski, AMNH). Huánuco: Monzón Valley, Tingo María, Oct. I9, I954, ㅇ, ơ (E. I. Schlinger, E. S. Ross, CAS). Brazil. Minas Gerais: Matosinhos, o (MNHN). Guanabara: Teresópolis, 900-1000 m, March, 1946, o (H. Sick, AMNH). São Paulo: São Paulo, Jan. 1960, ơ (A. M. Nadler, AMNH) ; Jabaquara, Cidade São Paulo, 700-800 m, Dec. 1945, ㅇ, $\sigma^{\pi}$ (H. Sick, AMNH). Santa Catarina: Nueva Teutonia, lat $27^{\circ}$ I I' S, long $52^{\circ} 23^{\prime} \mathrm{W}$,,$\sigma^{\prime}$ (F. Plaumann, SMF).

\section{Chrysso arops sp. $n$.}

Figures 29, 30

Type. Male from Teresópolis, 900-1000 m alt., Est. Guanabara, Brazil (H. Sick), in the American Museum of Natural History. The specific name is an arbitrary combination of letters.

Description. Carapace with clypeus, labium, maxillae orange. Sternum black, except anterior portion. Legs orange to gray. Abdomen orange-white with several black spots (Fig. 29). Eyes subequal in size. Anterior median eyes one diameter apart, their radius from laterals. Posterior median eyes one and one-fourth diameters apart, one and one-half from laterals. Chelicerae with one tooth on the anterior margin. Abdomen as illustrated with a hump above spinnerets but without grooves (Fig. 29). Total length $2.4 \mathrm{~mm}$. Carapace 0.98 $\mathrm{mm}$ long, $0.93 \mathrm{~mm}$ wide. First femur $2.58 \mathrm{~mm}$; patella and tibia 2.50 $\mathrm{mm}$; metatarsus $2.34 \mathrm{~mm}$. Fourth patella and tibia $1.28 \mathrm{~mm}$.

Diagnosis. This species probably belongs to Chrysso, it is not cer- 
tain whether the palpus (Fig. 30) has a radix. The palpal structure separates $C$. arops from other Chrysso.

\section{Chrysso ribeirao sp. n.}

Figures 52-54

Type. Female from Ribeirão Pires, $700-800 \mathrm{~m}$ alt., Est. São Paulo, Brazil, Dec. 1945 (H. Sick), in the American Museum of Natural History. The specific name is a noun in apposition after the type locality.

Description. Carapace yellow-white with some gray around posterior margin. Sternum all black in most specimens, in some only partially. Legs yellow-white with a black band on distal end of first femora and first tibiae. Abdomen with black and white areas and a median dorsal white band (Fig. 52). Eyes subequal in size. Anterior median eyes their diameter apart, almost touching laterals. Posterior median eyes their diameter apart, two-thirds from laterals. Abdomen without grooves (Fig. 52). Total length $2.7 \mathrm{~mm}$. Carapace 0.89 $\mathrm{mm}$ long, $0.77 \mathrm{~mm}$ wide. First patella and tibia $1.8 \mathrm{~mm}$; second 1.04 $\mathrm{mm}$; third $0.74 \mathrm{~mm}$. fourth $\mathrm{I} .22 \mathrm{~mm}$.

Diagnosis. The curved connecting ducts opening near the posterior rim (Figs. 53, 54) separates this species from others. The distance between the opening and the rim is variable.

Records. Brazil. Guanabara: Teresópolis, March I946, 3 \& paratypes (H. Sick, AMNH).

\section{Chrysso pulchra (Keyserling), new combination Figures 55-57}

Achaea signata Keyserling, 1891, Die Spinnen Amerikas, Brasilianische Spinnen, 3: 199, pl. 7, fig. 143, 9 . Female type from Alto da Serra do Novo Friburgo [Nova Friburgo, Est. Guanabara], Brazil in the British Museum, Natural History, examined. NEW SYNONYMY.

Achaea pulchra Keyserling, 1891, op. cit., p. 200, pl. 7, fig. 144, ㅇ. Female type from Alto da Serra do Novo Friburgo [Novo Friburgo, Est. Guanabara], Brazil in the British Museum, Natural History, examined.

Theridion pulchrum, - Roewer, 1942, Katalog der Araneae, 1:497.

Theridion signatellum Roewer, 1942, op. cit., p. 498. New name for signata, thought to be preoccupied by Theridion signata Walckenaer, 1805. NEW SYNONYMY.

Comments. Although signata has page priority, it will help nomenclatural stability to use the name pulchra, since Theridion signata is preoccupied and some authors might consider Chrysso and Theridion synonymous. The types of signata and pulchra differ only in the coloration of the abdomen, a variable character. Chrysso pulchra has the 
dorsum of the abdomen black, the sides white, and the venter yellowish without pigment (Fig. 55). The carapace and palpi of this species are black. The illustrations were prepared from the types of Achaea pulchra.

\section{Chrysso caraca sp. $\mathrm{n}$.}

Figures 6I, 62

Type. Female from Caraca, Minas Gerais, Brazil (E. Gounelle), in the Muséum National d'Histoire Naturelle, Paris (no. 888I). The specific name is a noun in apposition after the type locality.

Description. Carapace yellow. Sternum yellow, gray or black. Legs yellow, sometimes with irregular black marks. Abdomen with a median longitudinal dorsal white band and white patches on sides; a black spot on each side of posterior tip and sometimes a black patch on each side. Carapace fairly high. Anterior median eyes slightly smaller than others, their diameter apart, one-quarter from laterals. Posterior median eyes one diameter apart, their radius from laterals. Chelicerae with two teeth on anterior margin, probably none posterior. Abdomen barely longer than high. Total length $2.9 \mathrm{~mm}$. Carapace $0.98 \mathrm{~mm}$ long, $0.79 \mathrm{~mm}$ wide. First femur, I.7 I mm; patella and tibia, I.69 $\mathrm{mm}$; metatarsus, I.43 $\mathrm{mm}$; tarsus, $0.62 \mathrm{~mm}$. Second patella and tibia, I.00 $\mathrm{mm}$; third, $0.59 \mathrm{~mm}$; fourth, I. I $2 \mathrm{~mm}$.

Diagnosis. The opening of the epigynum is bordered by an anterior lip (Fig. 62) unlike C. pulchra; the shorter, straighter ducts (Fig. 6r ) separate this species from $C$. ribeirao.

Records. 3 paratypes collected with type.

\section{Chrysso backstromi (Berland), new combination}

Figures 58-60

Theridion bäckströmi Berland, 1924, The Natural History of Juan Fernandez and Easter Island, 3:426, figs. 4-6, ㅇ. Female type from Juan Fernandez Island, [Chile] in the Naturhistoriska Riksmuseum, Stockholm, examined.

Description. Yellow-white with white and black markings (Fig. $58)$. Legs yellow-white with black rings on ends of femora and tibiae of fourth leg. Anterior median eyes smaller than others, a little more than one diameter apart, their radius from laterals. Posterior eyes two-thirds their diameter apart. Eyes appearing white and relatively large. Chelicerae without teeth. Abdomen with a hump (Fig. 58). Total length $2.5 \mathrm{~mm}$. Carapace, I.I mm long, I.O mm wide. First femur, $2.2 \mathrm{~mm}$; patella and tibia, $2.2 \mathrm{~mm}$; metatarsus, $2.0 \mathrm{~mm}$; tarsus, $0.9 \mathrm{~mm}$. Second patella and tibia, I. $3 \mathrm{~mm}$; third, $0.9 \mathrm{~mm}$; fourth $\mathrm{I} .5$ $\mathrm{mm}$. 
Chrysso clementinae (Petrunkevitch), new combination Figures 71-75; Map I

Meotipa clementinae Petrunkevitch, 1930, Trans. Connecticut Acad. Sci., 30 : 212, fig. 61, 9 . Female type from Bayamón, Puerto Rico, in Petrunkevitch personal collection. Schmidt, 1956, Zool. Anz., 15: 240. [Not Bryant, 1940, Bull. Mus. Comp. Zool.. 86: 314, figs. 79, 80, ô ].

Description. Color white, with narrow reddish line in thoracic region, some scattered black spots on venter of legs and white pigment spots and some scattered small spots on dorsum of abdomen. Eyes subequal in size. Anterior median eyes a little more than one diameter

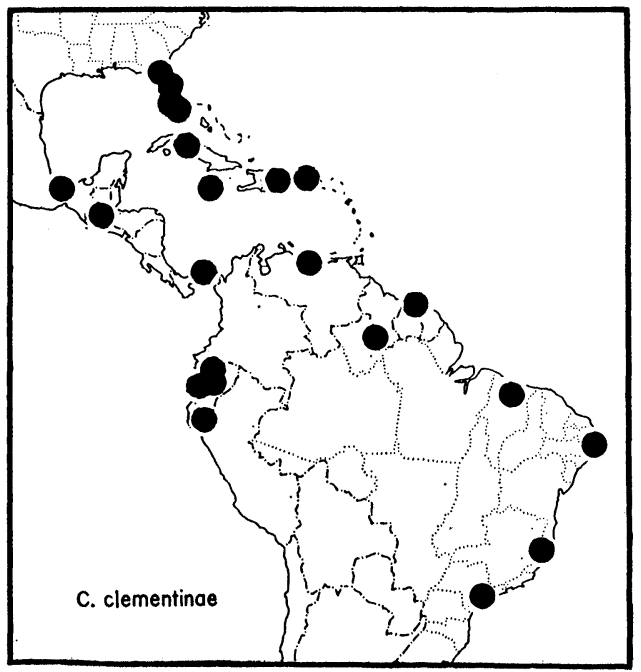

Map. 1. Distribution of Chrysso clementinae (Petrunkevitch).

apart, almost touching laterals. Posterior eyes separated by about one diameter. Abdomen often with several strong feather shaped (? movable) spines near tip (Fig. 7I). Epigynum with two dark spots in a lightly sclerotized area (Fig. 73). Male palpus with a short embolus and large conductor (Figs. 74, 75). Total length of a female from Puerto Rico $2.3 \mathrm{~mm}$. Carapace $0.85 \mathrm{~mm} \mathrm{long,} 0.78 \mathrm{~mm}$ wide. First femur, $2.45 \mathrm{~mm}$; patella and tibia, 2.3 I mm; metatarsus, I.5 I $\mathrm{mm}$; tarsus, $0.6 \mathrm{I} \mathrm{mm}$. Second patella and tibia, $\mathrm{I} .30 \mathrm{~mm}$; third, $0.8 \mathrm{I}$ $\mathrm{mm}$; fourth, $1.55 \mathrm{~mm}$. Total length of a male from Venezuela 2.0 $\mathrm{mm}$. Carapace $1.00 \mathrm{~mm}$ long, $0.78 \mathrm{~mm}$ wide. First femur $3.60 \mathrm{~mm}$; patella and tibia, $3.35 \mathrm{~mm}$; metatarsus, $3.45 \mathrm{~mm}$; tarsus, $0.9 \mathrm{I} \mathrm{mm}$. Second patella and tibia, $2.05 \mathrm{~mm}$; third, I.1 $3 \mathrm{~mm}$; fourth, $1.96 \mathrm{~mm}$. 
Natural History. This species is found on the underside of leaves of shrubs and small trees. Schmidt (1956) reports that it is commonly brought with bananas to Europe.

Distribution. Probably cosmotropical; the absence of closely related species in America might suggest that it has been introduced. (Schmidt, 1956, records having obtained specimens with fruit from Guatemala, Colombia, French West Africa and Belgian Congo).

Records. Florida. Alachua Co.: Gainesville (H. K. Wallace, Hubbell, AMNH). Dade Co.: Kendall (A. M. Nadler, AMNH). Highlands Co.; 3 mi. S of Lk. Istokpoga (A. M. Nadler, AMNH). Seminole Co.: near Geneva (W. J. Gertsch, AMNH). Mexico. Veracruz. $30 \mathrm{~km} \mathrm{~S}$ of Jesús Carranza; Lake Catemaco, $300 \mathrm{~m}$ (C. P. Vaurie, AMNH). Panama Canal Zone. Pedro Miguel; Corozal; Barro Colorado Island; Summit; France Field (all A. M. Chickering). Cuba. Vega Alta, Santa Clara (P. Bermudez); Soledad, Las Villas (P. J. Darlington). Jamaica. Mona, St. Andrew Par.; Gastonbury, Trelawny Par.; Rio Cobre Gorge, St. Catherine Par.; Ewarton, St. Catherine Par. (all A. M. Chickering) ; Kinloss (A. M. Nadler, AMNH). Dominican Republic. near Ciudad Trujillo (A. M. Nadler, AMNH); Boca Chica (A. M. Nadler, AMNH). Puerto Rico. Rio Piedras (A. M. Nadler, AMNH). Venezuela. Aragua: Maracay; Rancho Grande (A. M. Nadler, AMNH). Dto. Federal: Caracas (A. M. Nadler, AMNH). British Guiana. SauriWau River near Rio Tacutae (W. G. Hassler, AMNH). Surinam: Paramaribo (A. M. Nadler, AMNH). French Guiana. Cayenne (A. M. Nadler, AMNH). Ecuador. Pichincha: $35 \mathrm{~km} \mathrm{NW}$ of Santo Domingo de los Colorados (A. M. Nadler, AMNH). Tun-

\section{Explanation of Plate 17}

Figs. 71-75. Chrysso clementinae (Petrunkevitch). 71. Female, lateral view. 72. Female genitalia, dorsal view. 73. Epigynum. 74. Left palpus. 75. Palpus expanded, submesal view.

Figs. 76-78. C. questona sp. n. 76. Female abdomen, lateral view. 77. Female genitalia, dorsal view. 78. Epigynum.

Fig. 79. C. melba sp. n., palpus.

Figs. 80, 81. C. vesiculosa (Simon) (Philippines), Epigynum.

Figs. 82, 83. $C$. alecula sp. n. 82. Female genitalia, dorsal view. 83. Epigynum.

Figs. 84, 85. C. arima sp. n. 84. Female genitalia, dorsal view. 85. Epigynum.

Figs. 86-90. $C$. silva sp. n. 86. Female. 87. Female genitalia, dorsal view. 88. Epigynum. 89. Palpus. 90. Palpus expanded, subventral view.

Figs. 91-95. C. volcanensis sp. n. 91. Female. 92. Female genitalia, dorsal view. 93. Epigynum. 94. Palpus expanded, cymbium removed, dorsal view. 95. Palpus. (C, conductor; E, embolus; $M$, median apophysis; $\mathrm{P}$, paracymbium; $R$, radix; Y, cymbium). 
Psyche, 1962

Vol. 69, Plate 17
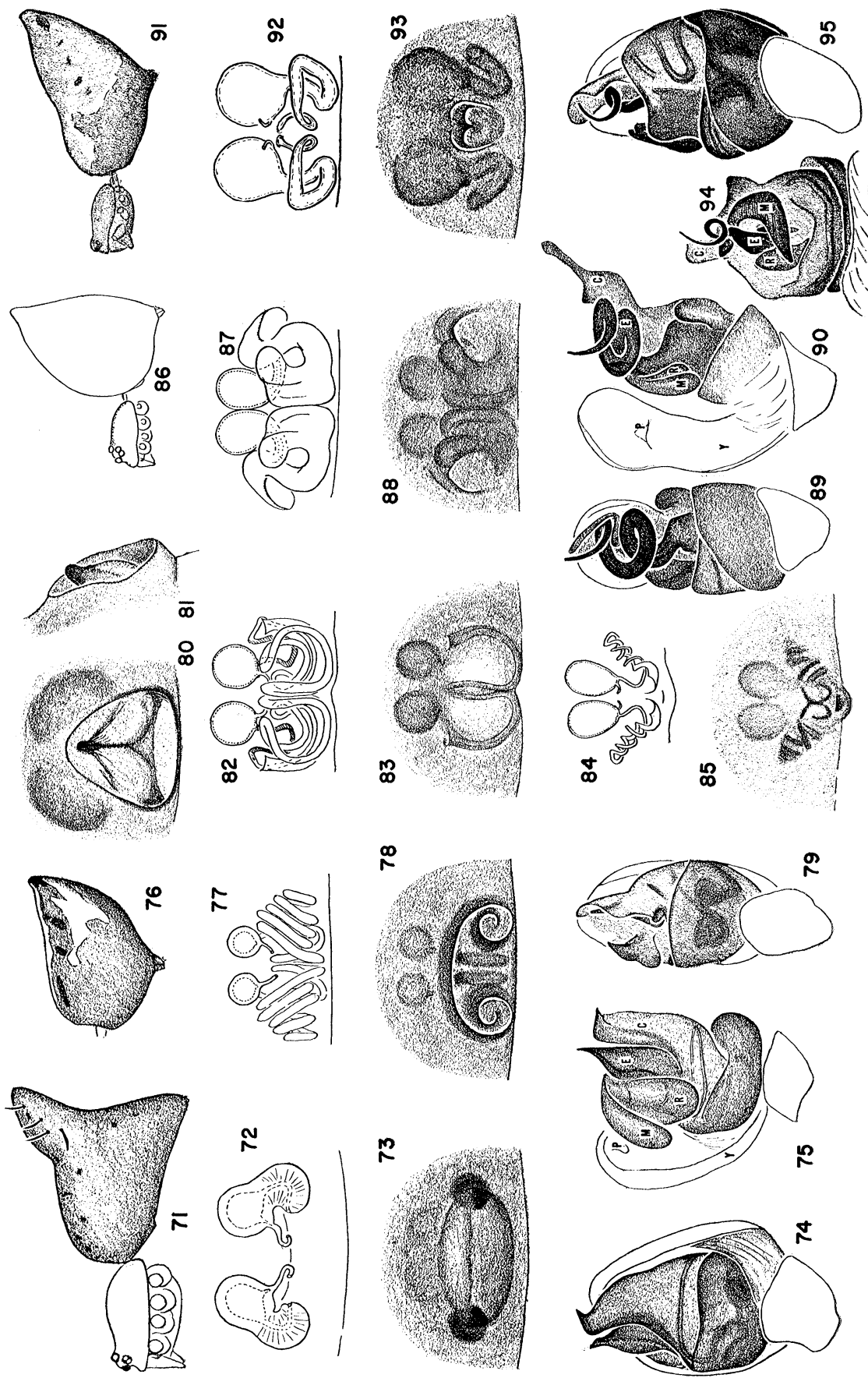
gurahua: Baños (H. E. Frizzell) ; Puñapi (H. E., D. L. Frizzell). Guayas: Milagro (H. E., D. L. Frizzell). Peru. "San Martin" (J. C. Pallister). Piura: Bellavista, Prov. Jean, (D. L. Frizzell). Brazil. Maranhão: São Luís (A. M. Nadler, AMNH). Pernamibuco: Recife (A. M. Nadler, AMNH). Espírito Santo: Santa Teresa (A. M. Nadler, AMNH). São Paulo: São Paulo (A. M. Nadler, AMNH). Paraguay. San Luis [?].

\section{Chrysso melba sp. n.}

Figure 79

Type. Male from Summit, Panama Canal Zone, July 21-29, I950 (A. M. Chickering) in the Museum of Comparative Zoology. The specific name is an arbitrary combination of letters.

Description. Yellow-white with a dusky median band on carapace, ends of femora, on patella, and distal ends of tibiae and metatarsi. Dorsum of abdomen with two rows of about ten dusky bars. Eyes subequal in size; anterior median eyes, one and one-third diameters apart, their radius from laterals. Posterior median eyes one and onehalf diameters apart, a little more than one from laterals. Chelicerae with two teeth on anterior margin. Abdomen longer than wide or high; highest above spinnerets. Total length $2.2 \mathrm{~mm}$. Carapace 1.0 $\mathrm{mm}$ long, $0.9 \mathrm{~mm}$ wide. First femur, $3.5 \mathrm{~mm}$; patella and tibia, 3.5 $\mathrm{mm}$; metatarsus, $3.7 \mathrm{~mm}$; tarsus, $1.2 \mathrm{~mm}$. Second patella and tibia, $2.0 \mathrm{~mm}$; third $0.9 \mathrm{~mm}$; fourth, $1.7 \mathrm{~mm}$.

Diagnosis. The palpal structure (Fig. 79) separates this species from C. clementinae.

\section{Chrysso alecula sp. $n$.}

Figures 82, 83

Type. Female from El Valle, Panama, July 1936 (A. M. Chickering) in the Museum of Comparative Zoology. The specific name is an arbitrary combination of letters.

Description. Yellow-white with a dusky median band on carapace, small dark spots on venter of legs and white pigment spots and some dusky marks on dorsum of abdomen. Eyes subequal in size. Anterior median eyes their diameter apart, one-fourth from laterals. Posterior median eyes one-half diameter apart, one-fourth from laterals. Shape of abdomen like that of $C$. silva (Fig. 86). Total length of female, I. $6 \mathrm{~mm}$. Carapace, $0.68 \mathrm{~mm}$ long $0.65 \mathrm{~mm}$ wide. First femur, I.7 I $\mathrm{mm}$; patella and tibia, I.6I $\mathrm{mm}$; metatarsus, $\mathrm{I} .43 \mathrm{~mm}$; tarsus, 0.50 
mm. Second patella and tibia, $1.06 \mathrm{~mm}$; third, $0.7 \mathrm{I} \mathrm{mm}$; fourth, I.I $7 \mathrm{~mm}$.

Diagnosis. The long loosely coiled ducts of the genitalia (Figs. 82, 83) separate this species from $C$. arima.

Records. Panama: El Valle, July 1936, ㅇ paratypes (A. M. Chickering).

\section{Chrysso arima sp. n.}

\section{Figures 84,85}

Type. Female from Simla, near Arima, Trinidad, 28 Dec. 1954 (A. M. Nadler) in the American Museum of Natural History. The specific name is a noun in apposition after the type locality.

Description. Yellow-white with white pigment spots on dorsum of abdomen. Eyes subequal in size. Anterior median eyes separated by one diameter, one-fourth from laterals. Posterior eyes separated by one diameter. Total length of female $1.6 \mathrm{~mm}$. Carapace, $0.63 \mathrm{~mm}$ long, $0.52 \mathrm{~mm}$ wide. First femur, I.42 $\mathrm{mm}$; patella and tibia, I.28 $\mathrm{mm}$; metatarsus, $0.98 \mathrm{~mm}$; tarsus, $0.50 \mathrm{~mm}$. Second patella and tibia, $0.80 \mathrm{~mm}$; third, $0.53 \mathrm{~mm}$; fourth, $0.98 \mathrm{~mm}$.

Diagnosis. The narrow, tightly coiled ducts of the genitalia and the median opening (Figs. 84, 85) separate this species from C. alecula.

Record. Trinidad. Simla near Arima, o paratype (A. M. Nadler).

\section{Chrysso silva sp. n.}

Figures 86-90

Type. Male from Furest Reserve, Panama Canal Zone, 25-28 July I954 (A. M. Chickering) in the Museum of Comparative Zoology. The specific name is an arbitrary combination of letters.

Description. Yellow-white with a median longitudinal dusky band on carapace; abdomen with white pigment patches on dorsum, dusky on sides. Anterior median eyes subequal or slightly larger than others, three-quarters diameter apart, almost touching laterals. Posterior eyes separated by one-third their diameter. Abdomen much higher than long in female (Fig. 86). Total length of a female, I.6 mm. Carapace $0.65 \mathrm{~mm}$ long, $0.59 \mathrm{~mm}$ wide. First femur, $1.56 \mathrm{~mm}$; patella and tibia, I.43 $\mathrm{mm}$; metatarsus, $\mathrm{I} .30 \mathrm{~mm}$; tarsus, $0.45 \mathrm{~mm}$. Second patella and tibia, $0.88 \mathrm{~mm}$; fourth, $0.97 \mathrm{~mm}$. Total length of male $\mathrm{r} .4 \mathrm{~mm}$. Carapace, $0.66 \mathrm{~mm}$ long, $0.66 \mathrm{~mm}$ wide. First femur, $1.70 \mathrm{~mm}$; patella and tibia, $1.75 \mathrm{~mm}$; metatarsus, $\mathrm{I} .53 \mathrm{~mm}$; tarsus, $0.52 \mathrm{~mm}$. Second patella and tibia, I.09 $\mathrm{mm}$; third, $0.63 \mathrm{~mm}$; fourth, $0.98 \mathrm{~mm}$. 
Diagnosis. The larger diameter and shortness of the female ducts (Figs. 87, 88) separate this species from $C$. alecula and $C$. arima. The large coiled embolus of the palpus (Fig. 89) is distinctive.

Natural History. This species is found by beating vegetation.

Records. Panama. Porto Bello, 우 (A. M. Chickering). Panama Canal Zone. Forest Reserve, ot paratype (A. M. Chickering) ; Summit, o paratype (A. M. Chickering, A. M. Nadler, AMNH); Barro Colorado Island, + , $\sigma^{\top}$ paratypes (A. M. Chickering, A. M. Nadler, AMNH) ; Madden Dam (A. M. Chickering); Ft. Randolph (A. M. Chickering). Ecuador. El Oro: Río Jubanes, Pasaje, Oct. 23, I942, ot (R. Walls).

\section{Chrysso volcanensis $\mathrm{sp} . \mathrm{n}$.}

Figures 9I-95

Thwaitesia vittata, - Banks, 1929, Bull. Mus. Comp. Zool., 69: 86. Not $C$. vittata O. P.-Cambridge.

Type. Male from El Voicán, Panama, Aug. 9-I4, I950 (A. M. Chickering) in the Museum of Comparative Zoology. The species is named after the type locality.

Description. Carapace, sternum, legs yellow-white. Legs with dark bands on middle and ends of segments. Abdomen yellow-white with white pigment areas on dorsum, sometimes with small black spots (Fig. 9I). Anterior median eyes one and one-half diameters apart, their radius from laterals in female; one diameter apart, one-third diameter from laterals in male. Posterior median eyes a little more than one diameter apart, one from laterals. Total length of females $3.5-4.5 \mathrm{~mm}$. One female measured $3.7 \mathrm{~mm}$ total length. Carapace, I.2 $\mathrm{mm}$ long, $0.8 \mathrm{~mm}$ wide. First femur, $5.0 \mathrm{~mm}$; patella and tibia, $5.0 \mathrm{~mm}$; meta tarsus, $5.4 \mathrm{~mm}$; tarsus, I. $4 \mathrm{~mm}$. Second patella and tibia, $2.7 \mathrm{~mm}$; third, I.3 mm; fourth, $2.6 \mathrm{~mm}$. Total length of a male $2.5 \mathrm{~mm}$. Carapace I.2 $\mathrm{mm}$ long, I.O mm wide. First femur, $5.9 \mathrm{~mm}$; patella and tibia, $6.0 \mathrm{~mm}$; metatarsus, $7.5 \mathrm{~mm}$; tarsus, $1.7 \mathrm{~mm}$. Second patella and tibia, $3.6 \mathrm{~mm}$; third, $1.4 \mathrm{~mm}$; fourth, $2.6 \mathrm{~mm}$.

Diagnosis. The shorter ducts and embolus (Figs. 92-95) distinguish this species from C. questona. The epigynum (Fig. 93) has an indistinct shallow depression of variable shape. The small palpal embolus (Figs. 94, 95) separate the species from $C$. silva.

Records. Costa Rica: Santa María Dota (Tristan). Panama. El Volcán, + , ơ paratypes (A. M. Chickering).

LeVi, Herbert W.

\section{Literature Cited}

"1955" (1957). The spider genera Chrysso and Tidarren in America. Jour. New York Ent. Soc., 63 : 59-81. 
"1957" (1958). Spiders of the new genus Arctachaea. Psyche, 64: 102106.

Levi, HerberT W. and Lorna R. Levi

1962. The genera of the spider family Theridiidae. Bull. Mus. Comp. Zool. $127(1): 1-71$.

Uyemura, $T$.

1957. Colour change in two species of Japanese spiders. Acta Arachnologica 15: 1-10.

YAGINUMA, T.

1957. Two new conopisthine spiders from Japan. ibid. 15:11-16. 

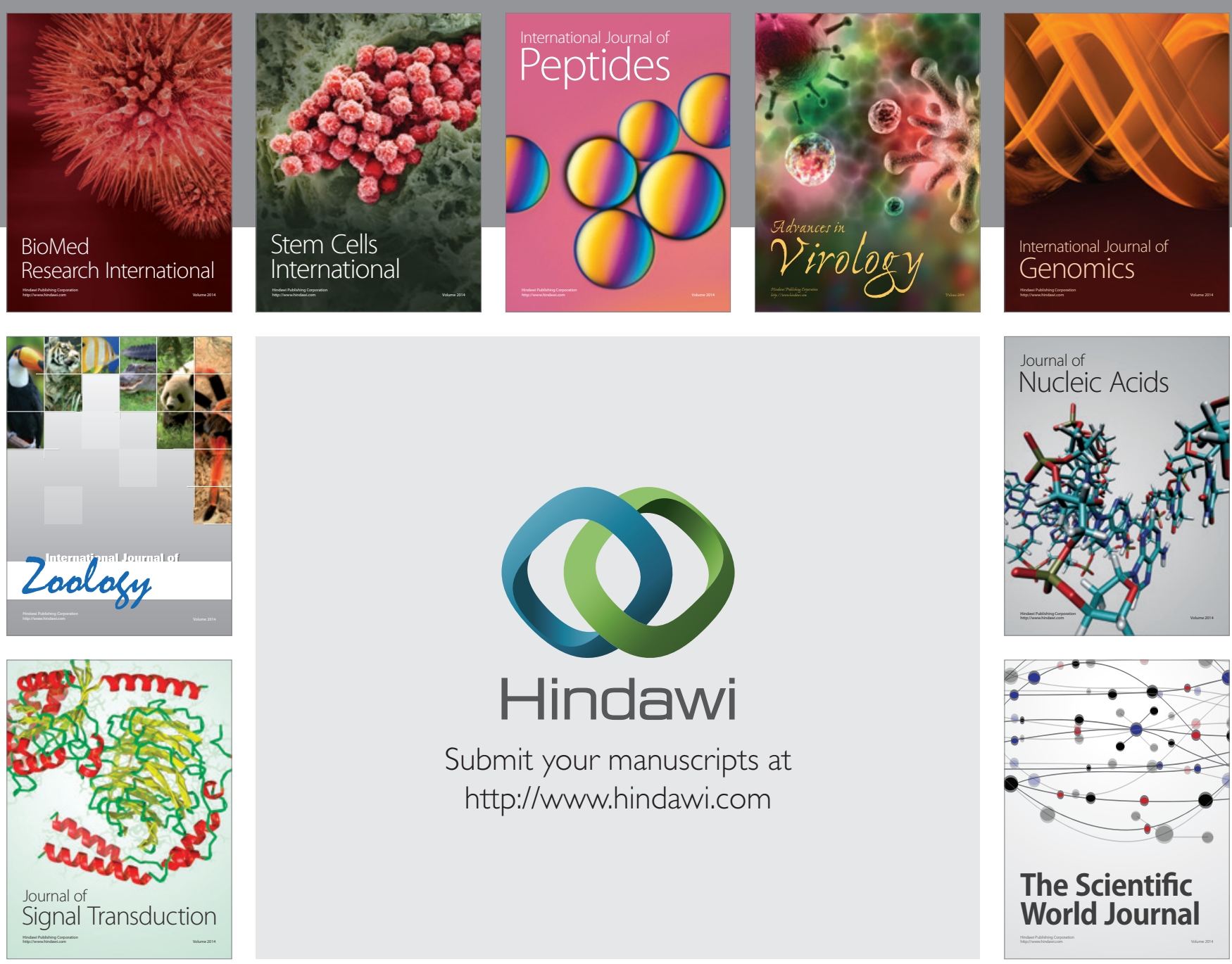

Submit your manuscripts at

http://www.hindawi.com
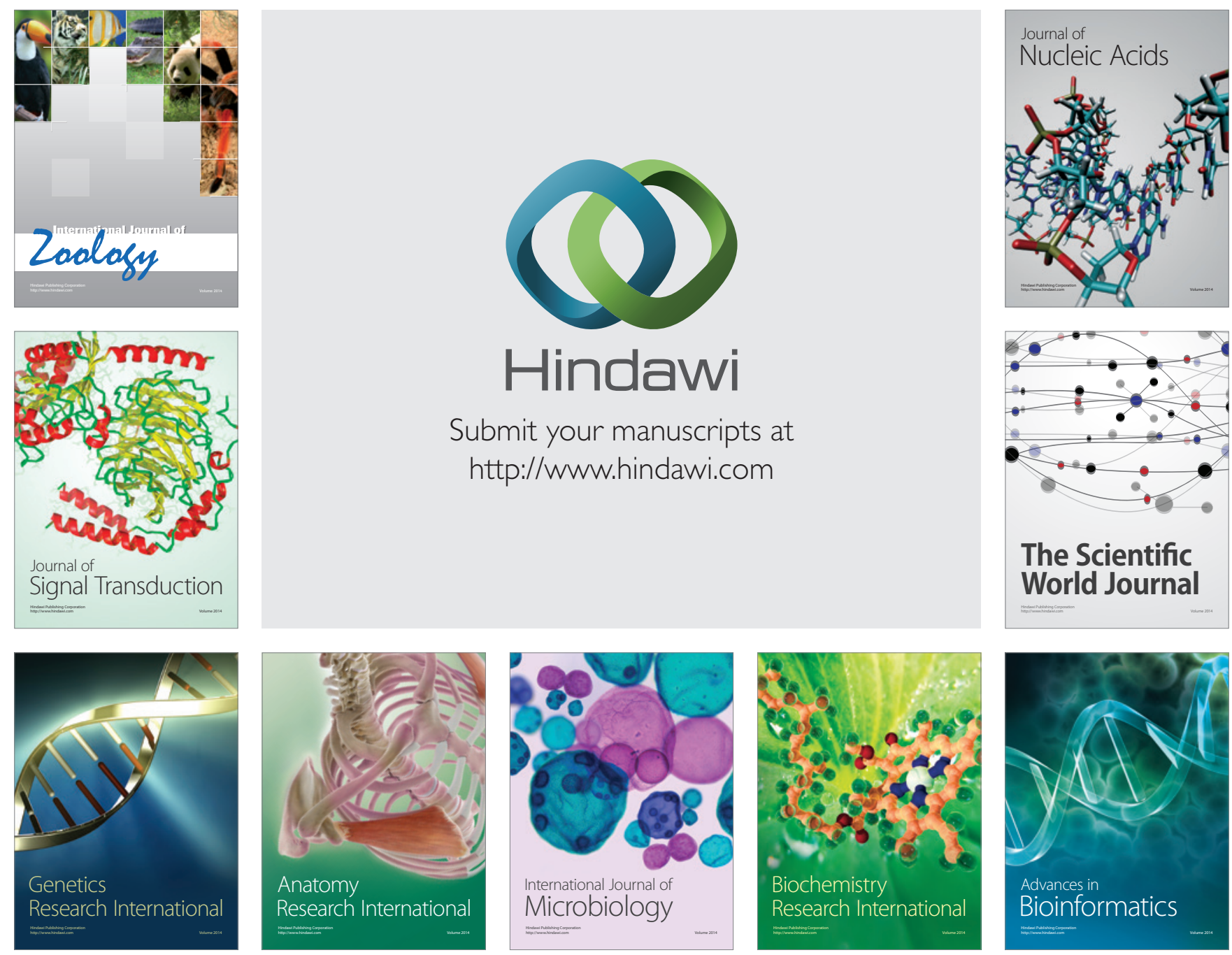

The Scientific World Journal
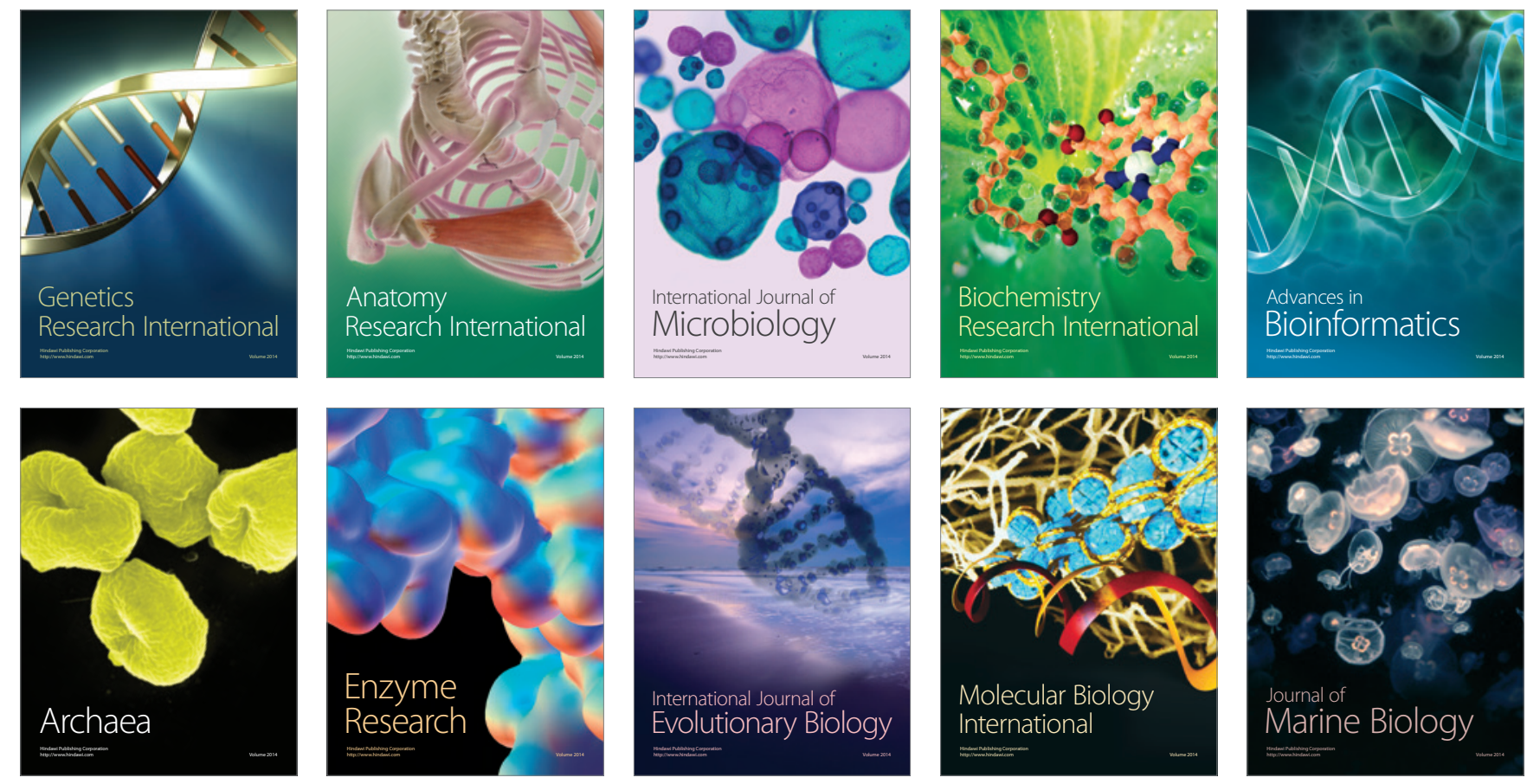